\title{
The Application of Sōgo Hyōka or Peer-Assessment on the Japanese Literature Introduction
}

\author{
Rima Devi ${ }^{1}$, Aulia Rahman ${ }^{2}$ \\ \{rimadevi@hum.unand.ac.id ${ }^{1}$, aulia@hum.unand.ac.id ${ }^{2}$ \} \\ 1,2Japanese Department Faculty of Humanities, Universitas Andalas, Padang, Indonesia
}

\begin{abstract}
This research is to examine how to enhance student ability to comprehend Japanese literature by applying the sōgo hyōka or peer-assessment method. Nowadays, students tend to not likely to read the textbooks such as the literature textbooks that impact to their understanding about the topics provided. The application of this method leads the student to figure out the topics of each meeting class. Students at the same time have to read the textbook and assess their colleague when presenting a topic. The students' attention is required not only just an audience but also as an assessor for colleagues. The results of this research reveal that student read the textbooks more actively and grasp the material well.
\end{abstract}

Keywords: Sōgo Hyōka, Peer-Assessment, Japanese literature.

\section{Introduction}

The Japanese Literature Introduction is a new subject that begins to implement in the Japanese Department Faculty Humanities Universitas Andalas in the 2018/2019 academic years. This course is a compulsory subject offered in semester two. After attending this lecture, the student is capable of explaining the history of Japanese literature from the earliest times of the formation of Japanese literature to the present. The expected achievement is the students can distinguish ancient or classical Japanese literature with modern and contemporary literature and Japanese literature developments.

This subject is an essential course as an introduction to Japanese literature. The understanding gained in this course will develop in the following semester courses related to literary theory and criticism of Japanese literature. By attending this lecture, the student can improve the ability to understand Japanese literature development. This lecture train students to express their opinions in discussions.

Regarding teaching materials, since this course is a new subject in the curriculums and there is no reference book provided, the team teaching selects materials from Indonesian textbooks containing an introduction to Japanese literature and Japanese literary history. In addition to strengthening understanding and finding links between Japanese literature history and Japanese society, Japanese history books are using too. The textbooks are old printed books that are quite helpful in providing understanding to students, how the outcomes obtained by using these teaching materials on the expected competencies are undetermined and proposed to evaluate learning by utilizing teaching materials in the textbooks as described above. 
The learning methods that have applied so far in the subjects that have similarities with the Japanese Literature Introduction courses are lectures, student discussions, and presentations. However, in reality, the student tends not to read the textbook. To develop students' reading interest in books, foster a desire to look for references on related webs, improve the ability to write papers and build collaboration in groups, then each week a group hold on presentation. However, at the peer group presentation, some students who became audiences paid little attention to the subject of the discussion. Moreover, from the assessment results identified, the students did not understand the material. The distribution of grades is very diverse, starting from A to E. A grades is for students who diligently and E grades for students who do not do the task and do not fulfill minimum attendance.

The problem of students, who do not read textbooks, especially if they become audiences, needs to be followed up so that learning outcomes are following the target. For this reason, in this study, a student assessment method was developed called sōgo hyōka or peer assessment. Sōgo hyōka is an assessment carried out by colleagues to other colleagues in a learning activity. Instructors have widely developed this method in various fields at schools and universities in Japan. The results of research on the application of the soggo hyokka method conducted in Japan showed that the level of understanding of learners about material increased and when assessments these learners generally obtained satisfactory grades and even tended to be very fulfilling [1], [2].

\section{Methodology or Strategy for Achieving Outcome}

Lecturer prepares and implements learning plans or RPS under the design that has set. The teaching method refers to the SCL (Student Centre Learning) method by dividing students into six presentation groups with topics that have determined, according to RPS. In this learning process, RPS is evaluated based on learning methods and student assessment.

The first meeting is an introduction and explanation of the lecturer regarding the course. Lecturer divided students into six groups, which will discuss six topics in six meetings to midterm test. Then after the midterm test, the students were divided back into six groups with different member formations, and each group was given a topic and presentation schedule for six meetings to the final test.

Each group received the topic and schedule of presentations and then prepared papers and slides for presentations. For the audience to be able to read the contents of the paper before the presentation begins, the paper is sent the latest one day before the presentation to the WhatsApp group that has previously formed. Also, the group prepares and distributes peer assessment sheets before the presentation begins. The group determines the member who will be moderators, presenters, operators for presentation slides, and minutes. When presentations and discussions take place, each group member has the same task in responding to questions or comments from the audience.

Students who become audiences each receive a peer assessment sheet. On this assessment sheet, students need to pay attention to the presentation and discussion well because they will provide assessment points, express the strengths and weaknesses of the group, provide suggestions and grades for the range of grades determined from 70 to 100 . The grade of 70 as a starting point with the assumption that is making papers and preparation for presentations is worth 70. This assessment sheet becomes a reference and assessment standard for students who are both peer-assessors and audiences when giving scores to presentation groups. The 
presentation group records each question and summarizes it in the notes to report at the next meeting. This note serves as a note for students to recall audience questions at previous meetings. This note can also be used to assess the students understanding of the material.

Lecturer collects and checks the peer assessment sheet to then succumb the following week to the group that has already presented. Groups of students who have been present can perceive how their peers assessed their presentation. This group calculates the average point. The point of group presentations every week is taken from the point given by colleagues.

This research was successful if the learning target were achieving, namely, students followed the lectures well according to the learning plan and obtained the distribution of grades $\mathrm{B}, \mathrm{B}+, \mathrm{A}-$, and $\mathrm{A}$. Achievement of learning is considering from students' understanding when facing middle term test and final test. Student responses to lectures observe from the peer assessment sheet. Completing the peer assessment sheet is included in the student assessment so that the calculations of student assessment are also parameters of the research results.

\section{Results and Discussion}

Learning of Japanese Literature Introduction occur well in two parallel classes, namely classes A and B. Each class consists of 32 first-year students, so the total is 64 students. The lectures last for one semester, that is 16 meetings with 12 times presentations, two times oration by the lecturer, midterm test, and final test. In presentation times, lecturer divided students in each class into six groups, and each group has the opportunity to present twice with different topics.

These first-year students are not familiar with the teaching method of presentations in front of the class. They also have not been trained to work together in teams to prepare presentation material. They are not yet proficient at explaining ideas and thoughts verbally in front of the audience. But progressively they began to adjust to the course every week so that on the occasion of the second presentation, they were becoming accustomed to it.

In general, students have not acquired the skill to read and summarize textbooks such as literature. It could be happening because the material and methods of teaching in high school are different from the University. Students who not habituate to reading textbooks, especially texts related to Japanese literature, attempt to read them little by little and ask questions in class about things that have not or are poorly understood. Not only that, students even questioned things even further, which emerged from reading comprehension. From the questions that they ask, the lecturer observes the level of student understanding of the material provided.

Students who tasked with presenting the material appears to be working hard to be able to respond to the audience's questions as best they can by opening and re-searching in the textbook that has read. From here, it can consider that both presenters and audience absorb and digest the material discussed. Lecturer confirmed their understanding of each material through examination i.e., midterm test and final test.

The distribution of grades from the two parallel classes is very satisfying results for the grade of students in general is A, only three students get an A-, one B + student and two students E. Students who get A- and B + are students who infringe the rules in lecture that do not collect individual reading assignments, do not actively participate in group work, and can not answer the questions in the midterm test and final test while students who obtained an E 
were those who did not fulfill the minimum attendance. The student's grade indicates the comprehension of the student to the material.

At the end of presenting each of the groups, students who become audiences respond to their colleagues' presentation. The students write a response to the peer assessment sheet obtained by each audience before the presentation begins - average points of audience grades that range from 80-90 points. However, audience assessment and comments did not focus on the material, but on performance during presentations. The response from the audience is such as presentation group members collaborate or not in the teams, presentation slides are useful or not, respond to audience questions is well or poorly explained, and papers are sent in WhatsApp group well written or there was an error. The response from the audience focused on the performance made the group that will present the following week trying to prepare better than the previous group. Lecturer identified the student's response to peer assessment working accordingly and obtaining positive comments. Such as students assessing their colleagues and then being used as a mirror to assess themselves, students attempt to prepare the best performance, students read material seriously and write points from material on presentation slides and communicate between group members in the sharing of tasks.

\section{Conclusions}

The sōgo-hyōka method, or peer-assessment, was successfully applying in the Japanese Literature Introduction course. The successful could determine to, the first, the distribution of student grades is remarkable, that is $92 \%$ of students obtain A grade. Second, the peer assessment sheet becomes an indicator of student response about the learning progress. Third, the student comprehends about the material and can re-explain the material through the midterm test and final test. Based on the results obtained from the application of learning methods, it knows that the soggo-hyōka or peer-assessment is very appropriate to apply in the Japanese Literature Introduction courses whose lecture material is a textbook that must read and understood by each student. Students who are not interested or do not understand how to read and extract the essence of a textbook, through this method they have come interested in reading textbooks so that they can be actively involved in each discussion.

\section{References}

[1] Kanenishi, K.: Sōgo hyōka mochiita repōto kadai shien shisutemu no kōchiku. Tokushima University (2013).

[2] Watanabe, F.: Sōgo hyōka donyūshita taikobo kōkai online kōza no settei oyobi sono hyōka to gakusei no tokusei to no kanren. Waseda University (2017). 